\title{
SOCJOLOGIA ANIOŁA
}

Z Michaelem Burawoyem, byłym przewodniczącym Amerykańskiego Towarzystwa Socjologicznego (ASA) i wiceprzewodniczącym Międzynarodowego Towarzystwa Socjologicznego (ISA), rozmawia Michał Łuczewski

Michał Luczewski: Jesteś ewangelistą?

Michael Burawoy (śmiech): O tak, socjologia obywatelska to dla mnie prawie religia.

MŁ: Co chcesz nam ogłosić?

MB (śmiech): Ewangelię socjologii, która reprezentuje interes społeczeństwa, narodu i ludzkości, socjologii, która stara się być odpowiedzialna nie tylko przed samą sobą, ale również przed ludźmi. Wymaga to przetłumaczenia naszego języka na język, który jest zrozumiały. Naukowiec nie powinien być tylko naukowcem, ale również obywatelem. To jest istota, raison d'etre socjologii. Mam doktorantów, którzy to rozumieja. Sa zdumieni, jak wszystko wokół nas, na uniwersytetach zostało sprofesjonalizowane. Jeśli nie pozwolono by im być socjologami obywatelskimi, odeszliby. To nie ma być konwersacja między nami, ale konwersacja ze społeczeństwem! Nie ma to nic wspólnego z polityką prawicy czy lewicy, z takimi czy innymi moralnymi podstawami, bo samo społeczeństwo obywatelskie mieści w sobie bardzo różne moralne podstawy.

MŁ: Głosisz to już od sześciu lat we wszystkich zakattach globu. Gdzie cię najlepiej przyjmują? Czy gdzieś potraktowali cię jak mesjasza?

MB: Nie jestem mesjaszem dla nikogo. Spontaniczna reakcja na to, co mówię, to krytyka. Profesjonalni socjologowie sa zawsze poirytowani. Charles Tilly krzywił się: „,socjologia obywatelska? To socjologia charytatywna!”. To wszystko zależy od miejsca w polu narodowej socjologii. W Ameryce zawsze znajdzie się kilka osób na marginesie, spychanych na bok, które 
czują się podbudowane przez to, że przewodniczący ASA czy wiceprzewodniczacy ISA ich wspiera. W Chinach zaimportowano po prostu socjologię amerykańską. Mam przyjaciół na elitarnych chińskich uniwersytetach, którzy są bardzo zaangażowani w socjologię obywatelska. Traktują to jako reakcję na amerykańską hegemonię w socjologii chińskiej. Oczywiście, nie traktują mnie jak mesjasza, ale używają do tego, by zrobić miejsce dla krytycznej socjologii obywatelskej. W Brazylii kilka osób było urzeczonych tą idea, ale tam jest to oczywiste, że socjologia musi być obywatelska. W Południowej Afryce mają mi za złe, że wyżej cenię socjologię obywatelską niż stosowana, ukierunkowaną na policy, ponieważ żeby tam przetrwać, musisz pracować dla rządu. Nie podoba im się moja idea i mówią, że socjologia obywatelska jest luksusem, na który może sobie pozwolić tylko socjologia zachodnia.

MŁ: Ale czy rzeczywiście nie jest to luksus? Czy do zajmowania się socjologia obywatelską nie trzeba mieć najpierw stabilnej pozycji naukowej?

MB: Nie. Moi przyjaciele w Południowej Afryce zostali zamordowani za to, że angażowali się społecznie. Nawet mój najbliższy przyjaciel! Jeśli byłeś zaangażowany w projekt socjologii obywatelskiej, było to naprawdę niebezpiecznym zajęciem. Bourdieu uważał, że najpierw musisz zebrać intelektualny kapitał i kiedy jesteś już na szczycie, np. w College de France, wtedy możesz być, a nawet powinieneś być socjologiem obywatelskim. Pod koniec życia również Tilly chciał być socjologiem obywatelskim, stąd brało się jego zainteresowanie terroryzmem, zagrożeniami demokracji. Ale to za późno. Socjologiem obywatelskim możesz być od początku. Jest miejsce w akademii, żeby uprawiać socjologię obywatelska. Jest na to miejsce w Polsce, jeśli chcesz, jeśli naprawdę bardzo chcesz.

ME: Skoro projekt socjologii obywatelskiej jest projektem moralnym, dlaczego - jak zauważasz - tak wielu ją demonizuje? Skoro jesteś ewangelista dobrej sprawy, dlaczego traktuja cię jak antychrysta?

MB: Tak przecież jest zawsze. Choć uważam, że socjologia nie może rozwijać się bez socjologii profesjonalnej, to widzę również, że sama jest polem dominacji. Jeśli podważasz dominację, pojawia się konflikt. Socjologowie maja swoje interesy, ich reputacja oparta jest na wiedzy, którą produkują, walidowanej przez recenzje. Obawiają się, że kiedy zaczną być odpowiedzialni również przed współobywatelami, naukowość ich pracy zostanie podana w watpliwość. Interes socjologii profesjonalnej jest sprzeczny $z$ interesem socjologii obywatelskiej. To wojna, to konflikt. 
W moich artykułach pokazuję, jak pozycja moich adwersarzy zależy od ich miejsca w polu naukowym. I jestem zadowolony z tego, że jest konflikt, że jest debata. Dążę do tego.

MŁ: Czym w takim razie jest dla ciebie socjologia?

MB: Definiuję socjologię poprzez miejsce, z którego przemawia. Socjologia genetycznie wzrastała razem ze społeczeństwem obywatelskim. Weber, Marks, Durkheim - każdy z nich zastanawiał się nad istotą społeczeństwa obywatelskiego.

MŁ: Ale w takim rozumieniu socjologii nie ma miejsca na takie pojęcia, jak wyjaśnienie, opis, prawda.

MB: Wierzę w rozwój programów badawczych w sensie Lakatosa, paradygmaty jednak są różne. Oprócz twierdzeń naukowych posiadaja również moralne podstawy. I to, co odróżnia socjologię od ekonomii czy politologii, to miejsce, z którego mówimy. Ekonomiści zajmują się gospodarka, politologowie - państwem, a socjologowie - społeczeństwem obywatelskim. Muszą oni bronić społeczeństwa, bo inaczej straciliby podstawę swojej własnej dyscypliny.

ML: Takie widzenie socjologii wydaje mi się bardzo defensywne. Raymond Boudon np. definiuje ja poprzez styl wyjaśnienia i pokazuje, że wyjaśnienia formułowane przez psychologię, politologię czy ekonomię są wyjaśnieniami cząstkowymi. Zadanie socjologii polega na tym, by łączyć wyjaśnienia cząstkowe w ogólne schematy wyjaśniające. A zatem podczas gdy Boudon widzi w socjologii królową nauk, tobie wystarcza, że wykrawasz dla niej kawałek przestrzeni życiowej między ekonomią i politologia.

MB: Masz rację. Boudon, podobnie jak Parsons, jest socjologicznym imperialista. Ale ja też nim jestem. Jesteśmy socjologicznymi szowinistami, tyle że rozpoczynamy od różnych punktów wyjścia. Być może jestem defensywny wobec ekonomii i politologii, ale ekspansywny w stronę społeczeństwa. My mamy reprezentować interes ludzkości! To jest prawdziwy imperializm. Boudon nie troszczy się o ludzkość, interesuje go tylko pieprzona nauka!

MŁ: Ale Boudon powiedziałby, że właśnie dlatego, że interesuje go ludzkość, zajmuje się nauką. 
MB: To tylko gest. Ja robię coś więcej, niż gest. Ja naprawdę chcę być zaangażowany w sprawy społeczeństwa obywatelskiego.

MŁ: Nie myślisz jednak, że pozycja Boudona jest silniejsza, bo może łatwo określić, czym jest dobra i czym jest zła socjologia? Twoja pozycja wydaje się bardziej chwiejna, bo trudniej znaleźć standardy tego, czym jest dobra socjologia obywatelska. Peter Berger np. boi się tego, że socjologię zniszczy zaangażowanie w race, gender, class, ponieważ zaczną w niej obowiązywać dwa standardy: socjologii profesjonalnej i socjologii zaangażowanej.

MB: To, co opowiada Berger, to nonsens. Nie można uprawiać nauki bez moralnych podstaw. Skąd się wzięła socjologia ruchów społecznych Tilly'ego? Przecież z moralnej rewolty 1968 r.! Oczywiście problemem jest, jak połączyć moralne podstawy z badaniem naukowym. W każdym programie badawczym istnieja pytania, których się nie zadaje i naukowcy odmawiaja przyznania, że moralne podstawy w ogóle istnieja. Gdy krytyczni socjologowie to pokazuja, wywołuje to powszechną wściekłość. Profesjonalna nauka może się rozwijać tylko wtedy, kiedy nie kwestionuje swoich zasad, kiedy nie zastanawia się nad swoimi podstawami. I to jest dobre. To tak, jak gra w szachy: grając w nie, nie zastanawiasz się, skąd biora się reguły i jakie jest ich moralne znaczenie. Berger nie lubi, kiedy się to pokazuje - i ja to rozumiem. Nie będziesz się rozwijał jako profesjonalista, jeśli nie weźmiesz w nawias swoich moralnych przekonań. Ale socjologia nigdy nie stworzy jedności, zawsze będzie oparta na konflikcie. Właśnie tak rozwija się nauka. Nie poprzez narzucenie swojego zdania innym, ale poprzez konflikt. Berger jest przerażony, gdy to mówię. Twierdzi, że niszczę socjologię, a ja odpowiadam, że dopiero dzięki temu socjologia staje się nauką.

MU: Jak łączyć moralne przekonania z badaniem? W swoich artykułach sugerujesz, że socjologia powinna to robić i w ostatecznym rachunku przekształcić się w ruch społeczny. Sam nawet taki ruch tworzysz, walczysz o społeczeństwo obywatelskie przeciw systemowi: rynkowi i państwu. Jako człowiek, który próbuje mobilizować innych, używasz określonego repertuaru. Nawet ubierasz się w sposób antysystemowy. Używasz też bardzo moralnej retoryki, która czerpie z retoryki religijnej: ewangelia, ludzkość, antychryst, demony, anioły. Dla mnie nie jest to retoryczny ornament, ale istota tego, co mówisz. Bez tego typu języka nie byłbyś w stanie porywać ludzi. 
MB: Myślę, że masz rację, jestem również członkiem ruchu społecznego. Istnieje na pewno napięcie między nauką a ruchem, ale twierdzę, że czasami, choć to bardzo niebezpieczne, możliwe jest ich połączenie. Kluczowa jest tutaj autonomia socjologii. Socjologia nie może być patologia, nie może być instrumentem ruchów społecznych.

MŁ: A czy może być instrumentem anioła historii?

MB: To był tylko symbol, którego użyłem na początku mojej przemowy, gdy zostałem przewodniczącym American Sociological Association w 2004 r. To był czas administracji Busha. Byłem bardzo pesymistyczny co do kierunku, w którym zmierza świat. Wszyscy socjologowie zgadzali się, że sytuacja USA jest fatalna. To był największy zjazd w historii ASA. Przyjechał Alain Touraine i myślał, że przeniósł się w lata 60. Nie mógł uwierzyć w to, co widzi, nie wiedział, co się dzieje. Nikt by nie pomyślał, że socjologia amerykańska będzie kiedyś zdolna do czegoś takiego. Wokół nas panował niesamowity entuzjazm. Tysiące osób z całego świata! To był ten moment, kiedy mogłem się odwołać do Benjamina i jego figury anioła historii. W społeczeństwie, które się rozpadało, my, socjologowie, musieliśmy zebrać się razem. Touraine powiedział, że ma tylko jedno wyjaśnienie tego, co się dzieje: Bush is good for public sociology.

MŁ: Według Benjamina jednak anioł nie może nic zrobić, może tylko obserwować ruinę świata, która przynosi postęp - obserwować i czekać na apokalipsę. Dopiero wtedy tę ruinę może odkupić mesjasz, który przyjdzie spoza historii. Może również, razem z aniołem, powinniśmy czekać na prawdziwego mesjasza?

MB: Nie, musimy próbować już teraz. 